\title{
OPTIMALISASI PENGELOLAAN TERNAK SAPI DI DESA BIJAEPUNU MELALUI PENERAPAN TEKNOLOGI INFORMASI DAN KOMUNIKASI
}

\author{
Folkes E. Laumal $^{1)}$, Gloria Manulangga ${ }^{2)}$, Kusa Bill Nope ${ }^{3)}$ \\ ${ }^{1), 2)}$ Program Studi Teknik Komputer dan Jaringan Politeknik Negeri Kupang \\ ${ }^{3)}$ Program Studi Teknik Sipil Politeknik Negeri Kupang \\ Email:folkeslaumal76@gmail.com,gloriamanulangga@gmail.com,kusa_nope@yahoo.co.id
}

\begin{abstract}
ABSTRAK
Dukungan topografi yang baik dan adanya MOU antara NTT dan DKI Jakarta tentang pengelolaan ternak sapi, telah memberikan pengaruh yang positif bagi masyarakat NTT untuk mengembangkan ternak sapi, tidak terkecuali masyarakat di Desa Bijaepunu Kabupaten TTS. Namun, kemampuan sumber daya peternak yang masih rendah memerlukan sentuhan Teknologi Informasi dan Komunikasi (TIK) guna menunjang usaha beternak sapi. Apalagi di Bijaepunu telah tersedia prasarana Base Transmiter Station (BTS) dari Telkom. Pengabdian ini telah memprogramkan kegiatan pengembangan sumber daya manusia tentang pemanfaatan fasilitas TIK untuk mengoptimalkan usaha ternak sapi di Bijaepunu yang meliputi pengetahuan ternak, informasi pemasaran, strategi penjualan dan memperluas jaringan. Kegiatan telah dilaksanakan dengan teori dan praktek disertai pendampingan penggunaan fasilitas TIK. Hasil dari kegiatan menunjukkan adanya perubahan sosial masyarakat dimana peternak yang awalnya kurang mengetahui informasi tatakelola ternak dan pemasaran sapi (harga pasar dan perhitungan harga) akhirnya memahami tentang tatakelola ternak sapi yang optimal. Prasarana yang mereka sudah miliki (handphone) dan BTS yang tersedia di Bijaepunu akhirnya dapat dioptimalkan dalam jaringan internet untuk mencari informasi yang berkaitan dengan ternak sapi.
\end{abstract}

Kata Kunci: Teknologi Informasi dan Komunikasi, Internet, bijaepunu, ternak sapi.

\section{PENDAHULUAN}

Desa Bijaepunu terletak di Kecamatan Mollo Utara Kabupaten Timor Tengah Selatan memiliki kelompok-kelompok masyarakat pengelola usaha pertanian dan peternakan. Salah satu diantaranya adalah kelompok masyarakat Immanuel yang terlibat dalam usaha ternak sapi. Topografi Desa Bijaepunu memang cocok untuk pengembangan peternakan sapi karena terletak di dataran tinggi dengan suhu udara yang dingin dan sejuk. Selain itu adanya kerja sama ternak sapi antara pemerintah Nusa Tenggara Timur dan DKI Jakarta melalui MOU pengiriman ternak sapi, menyebabkan banyak komunitas masyarakat memilih untuk mengembangkan ternak sapi sebagai upaya pendukung program pemerintah[1][2].

Tahun 2016 kelompok ternak sapi di Desa Bijaepunu yang bernama Pokmas Immanuel dengan 30 anggotanya telah membudidayakan sekitar 150 ekor sapi bantuan pemerintah. Pembudidayaan dan pemeliharaan diatur dalam satu kawasan untuk memudahkan perawatan, selain masing-masing anggota juga memelihara jenis sapi lokal di pekarangan. Dalam pengolahan ternak sapi, anggota kelompok Immanuel mendapat bimbingan dari Tenaga Penyuluh Desa (PPD) Dinas Peternakan Kabupaten Timor Tengah Selatan, namun, dalam hal pemasaran dan penjualan ternak, rata-rata kelompok masih menentukan harga secara konfensional yaitu berdasarkan usia hidup ternak atau jumlah saudara/anak yang sudah dimiliki. Yang penting bagi kelompok adalah ternak mereka cepat terjual sehingga hasilnya dimanfaatkan untuk memenuhi kebutuhan hidup keluarga.

Cara konfensional ini dimanfaatkan oleh orang-orang tertentu untuk mengambil keuntungan pribadi, dimana mereka datang langsung ke peternak, membeli sapi berkualitas dengan harga rendah kemudian menjual kembali ke distributor dengan harga pasar yang sebenarnya (lebih mahal). Kecurangan lain yang terjadi yaitu mencari keuntungan dengan menebak berat sapi yang akan mereka beli dan melakukan negosiasi harga ke peternak. Sedangkan ketika berhadapan dengan distributor, mereka menggunakan timbangan ternak yang baik dan mereka mendapat keuntungan. Akibat dari kecurangan ini adalah bukan penghidupan masyarakat peternak sapi yang lebih sejahtera, tetapi orang-orang tertentu yang secara licik memainkan strategi pasar mereka untuk mengambil keuntungan. Kelompok masyarakat peternak sapi sangat minim mendapatkan informasi harga pasar terkini yang berlaku pada ternak sapi.

Jika ditinjau dari ketersediaan infrastruktur telekomunikasi, Desa Bijaepunu telah memiliki stasiun pemancar telekomunikasi (BTS) yang mendukung telekomunikasi publik dan dapat dimanfaatkan untuk 
membangun infrastruktur jaringan dan internet dalam kelompok masyarakat agar dapat dimanfaatkan untuk mencari dan menemukan berbagai informasi sesuai kebutuhan hidup mereka. Selain itu banyak masyarakat yang sudah menggunakan perangkat smartphone untuk kebutuhan komunikasi sehari-hari, walaupun hanya terbatas untuk SMS dan Telepon. Keterbatasan sumber daya manusia dalam memanfaatkan perangkat pintar juga menjadi kendala kemajuan peradaban masyarakat walaupun fasilitas penunjang telah tersedia.

Dengan kondisi masyarakat inilah maka diperlukan upaya peningkatan kemampuan sumber daya manusia dalam bidang Teknologi Informasi dan Komputer (TIK) kepada kelompok-kelompok masyarakat di Desa Bijaepunu agar dapat mengatasi masalah kesenjangan informasi pasar, manajemen pengelolaan ternak sapi, keterlambatan informasi dan keterbelakangan.

\section{METODE}

Optimalisasi pengelolaan ternak melalui penerapan TIK bagi masyarakat di Desa Bijaepunu dilaksanakan dalam beberapa tahapan, yaitu survey, penyiapan program, pelatihan, pendmapingan dan evaluasi. Survei dilakukan melalui diskusi bersama masyarakat dan tokoh masyarakat tentang tatakelola ternak sapi mulai dari pemeliharaan, perjanjian, penjualan dan harga pasar. Selanjutnya hasil diskusi dikaitkan dengan ketersediaan infrastruktur jaringan dan tren informasi yang memungkinkan untuk menjawab persoalan masyarakat. Tahapan selanjutnya adalah menyusun urgensi permasalahan dan target solusi agar program yang diimplementasikan nanti betul-betul tepat sasaran dan menjawab masalah di lapangan. Selanjutnya adalah persiapan materi, prasarana pendukung dan melaksanakan pelatihan pemanfaatan TIK bagi usaha peternakan sapi di Bijaepunu. Pelatihan dilakukan dengan cara tatap muka teori dan praktek langsung dilapangan bersama kelompok masyarakat, dilanjutkan dengan pendampingan dalam pemanfaatan fasilitas TIK untuk menemukan informasi yang berkatan dengan ternak sapi. Bagian akhir adalah evaluasi melalui pemberian penilaian dan reward kepada peserta yang mengikuti pelatihan.

\section{KAJIAN KONSEP}

\section{Base Transceiver Station}

Base Transceiver Station atau BTS yang mulai populer di era booming seluler berfungsi menjembatani perangkat komunikasi pengguna dengan jaringan menuju jaringan lain. Satu cakupan pancaran BTS dapat disebut Cell. Komunikasi seluler adalah komunikasi modern yang mendukung mobilitas yang tinggi. Dari beberapa BTS kemudian dikontrol oleh satu Base Station Controller (BSC) yang terhubungkan dengan koneksi microwave atau serat optik[3]. Meskipun istilah BTS dapat diterapkan ke salah satu standar komunikasi nirkabel, biasanya dan umumnya terkait dengan teknologi komunikasi mobile seperti GSM dan CDMA. Dalam hal ini, BTS merupakan bagian dari base station subsystem (BSS) perkembangan untuk sistem manajemen. Ini juga mungkin memiliki peralatan untuk mengenkripsi dan mendekripsi komunikasi, spektrum penyaringan alat (band pass filter), antena juga dapat dipertimbangkan sebagai komponen dari BTS dalam arti umum sebagai mereka memfasilitasi fungsi BTS. Biasanya BTS akan memiliki transceiver beberapa (TRXs) yang memungkinkan untuk melayani beberapa frekuensi yang berbeda dan berbagai sektor sel (BTS sectorised). Sebuah BTS dikendalikan oleh kontroler base station melalui fungsi base station kontrol (BCF). BCF ini dilaksanakan sebagai unit diskrit atau bahkan tergabung dalam TRX di BTS kompak. Para BCF menyediakan operasi dan pemeliharaan (koneksi dengan sistem manajemen jaringan (NMS) dan mengelola kondisi operasi dari TRX masing-masing, serta penanganan perangkat lunak dan koleksi alarm. Struktur dasar dan fungsi dari BTS tetap sama tanpa teknologi nirkabel[4].

\section{Teknologi Informasi dan Komputer}

Teknologi Informasi dan Komunikasi (TIK) adalah segala hal yang berhubungan dengan pengolahan informasi dan penyampaiannya dari pengirim ke penerima. Teknologi Informasi menekankan pada pelaksanaan dan pemprosesan data seperti menangkap, mentransmisikan, menyimpan, mengambil, memanifulasi atau menampilkan data dengan menggunakan perangkat-perangkat teknologi elektronik terutama komputer[5]. Makna teknologi informasi tersebut belum menggambarkan secara langsung kaitannya dengan sistem komunikasi, namum lebih pada pengolahan data dan informasi. Sedangkan teknologi komunikasi menekankan pada penggunaan perangkat teknologi elektronika yang lebih menekankan pada aspek ketercapaian tujuan dalam proses komunikasi, sehingga data dan informasi yang diolah dengan teknologi informasi harus memenuhi kriteria komunikasi yang efektif[6]. Sebagai contoh salah satu aplikasi Teknologi Informasi dan Komunikasi adalah video conference, yang menggunakan teknologi informasi untuk menghubungkan (networking) antar client dengan fasilitas internet, pesan-pesan 
yang disampaikan diterima, diolah, dianalisis dan ditrasmisikan oleh teknologi informasi sehingga sampai ke penerima melalui internet dengan jaringan nirkabel atau kabel[7]. Peran teknologi komunikasi adalah mengatur mekanisme komunikasi antar kedua belah pihak dengan cara desain komunikasi yang sesuai, visualisasi jelas, pesan teks, suara, video memenuhi standar komunikasi, pengaturan feedback sehingga komunikasi berlangsung menjadi dua arah. Implementasi TIK di masyarakat dapat dilakukan dalam bentuk pelatihan dan pendampingan tentang pemanfaatan dan pengelolaan jaringan komputer, pengolahan dan pembuatan video, pengiriman data antar komputer dan akuntansi berbasis komputer yang berdampak pada perubahan sosial di dalam anggota masyarakat (sekolah atau kelompok masyarakat) atau pada individu yang mengikuti kegiatan tersebut[8].

\section{Jaringan Komputer}

Jaringan komputer (jaringan) adalah jaringan telekomunikasi yang memungkinkan antar komputer untuk saling berkomunikasi dengan bertukar data. Tujuan dari jaringan komputer adalah agar dapat mencapai tujuannya, setiap bagian dari jaringan komputer dapat meminta dan memberikan layanan (service). Pihak yang meminta/menerima layanan disebut klien (client) dan yang memberikan/mengirim layanan disebut peladen (server). Desain ini disebut dengan sistem client-server, dan digunakan pada hampir seluruh aplikasi jaringan komputer. Dua buah komputer yang masing-masing memiliki sebuah kartu jaringan, kemudian dihubungkan melalui kabel maupun nirkabel sebagai medium transmisi data, dan terdapat perangkat lunak sistem operasi jaringan akan membentuk sebuah jaringan komputer yang sederhana. Apabila ingin membuat jaringan komputer yang lebih luas lagi jangkauannya, maka diperlukan peralatan tambahan seperti Hub, Bridge, Switch, Router, Gateway sebagai peralatan interkoneksinya. Implementasi Jaringan komputer dapat dilakukan pada koneksi antara 2 komponen elektronika (komputer dengan komputer, komputer dengan perangkat handphone atau antara 2 handphone) yang saling mengirimkan data satu dengan yang lain[9][10].

\section{PEMBAHASAN}

Optimalisasi pengelolaan ternak sapi melalui penerapan TIK bagi masyarakat Desa Bijaepunu dilaksanakan dalam 3 program, yaitu pembangunan infrastruktur jaringan internet, pelatihan dan pendampingan penggunaan prasarana TIK untuk peternakan sapi dan evaluasi program.

\section{Membangun infrastuktur jaringan dalam kelompok masyarakat Immanuel yang dapat dimanfaatkan untuk mencari berbagai informasi dari daerah lain terutama yang berhubungan dengan usaha ternak sapi.}

Proses pembangunan infrastruktur jaringan pada kelompok masyarakat di Bijaepunu yaitu Kelompok Masyarakat Immanuel yang memiliki keanggotaan \pm 30 peternak. Infrastruktur yang dibangun meliputi interkoneksi antara perangkat komputer, modem dan jaringan kabel serta instalasi perangkat lunak. Jaringan dan interkoneksi yang dibangun diberikan pada Gambar 1.

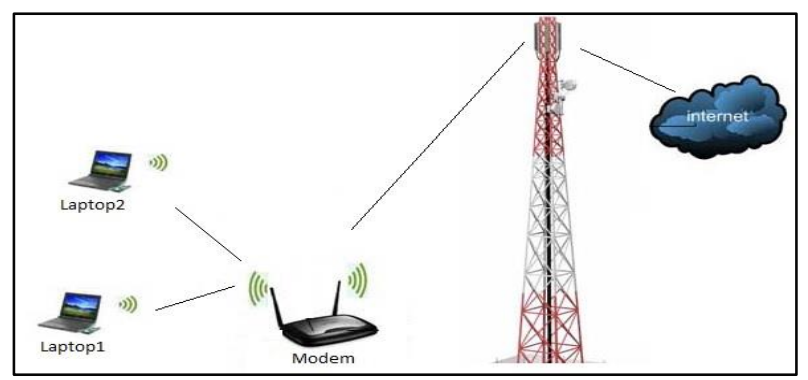

Gambar 1. Model Jaringan yang dibangun di Bijaepunu

Gambar 1 menjelaskan tentang model jaringan yang dibangun di Desa Bijaepunu. Karena pemacar BTS telah tersedia di wilayah desa tersebut, maka program ini hanya menyediakan modem dan perangkat komputer. Interkoneksi dari modem ke komputer selanjutnya di-setting dalam satu kelompok jaringan dan diberi password. Sehingga perangkat komputer atau handphone yang akan mengakses internet, harus mendapat ijin melalui password yang telah di-setting.

Pada jaringan Bijaepunu ini, konfigurasi SSID adalah : 
Nama SSID : bijaepunu_net

Password : bijaepunu

Kelompok Jaringan : Kelas C (192.168.1.100 - 192.168.1.115)

\section{Mengembangkan sumber daya manusia melalui kegiatan pelatihan penggunaan sarana telekomunikasi dan internet.}

Pelatihan penggunaan sarana TIK meliputi pengenalan Komputer dan perangkat jaringan yang berpeluang terkoneksi ke komputer, pengetahuan tentang browser sebagai mesin pencari, pembuatan direktori sebagai lokasi penyimpanan data/informasi, pembuatan email dan pengelolaan data/informasi menggunakan email. Bagian-bagian TIK yang diimplementasikan ke peternak di Bijaepunu dijabarkan pada Tabel 1 .

Tabel 1. Bagian TIK yang diimplementasikan kepada Peternak di Bijaepunu

Definisi Teknologi Informasi, definisi Internet, Peserta mengikuti dan memahami penjelasan dan manfaat Internet. simulasi-simulasi sederhana

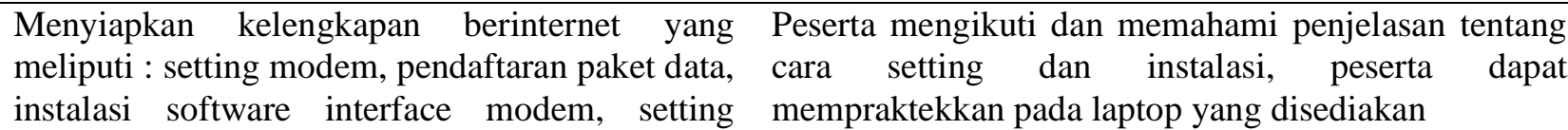
portable Wi-Fi hotspot (tethering)

Mengenal mesin pencari (browser) yang meliputi Peserta memahami dan dapat menjalankan masingInternet Explorer, Mozilla Firefox, Google masing browser, dapat melakukan setting tertentu Chrome, karakteristik, kelebihan dan pada menu setting di masing-masing browser.

kekurangannya.

Memanfaatkan google sebagai mesin pencari Peserta menggunakan google.com untuk mencari informasi, trik-trik menemukan kata kunci. informasi tentang teknologi Sapi, jenis-jenis sapi dan sebaran ternak sapi di daerah-daerah lain.

Mengenal dan menjelajahi blogger, menyalin Peserta memahami dan dapat melakukan download informasi text, gambar dan video dari internet data baik text, gambar maupun video dari halaman(download) halaman web/blog yang ditampilkan.

Pengenalan direktori sebagai lokasi penyimpanan dokumen, cara membuat dan menempatkan direktori yang baik, mengubah dan menghapus direktori, copy dan rename direktori.

Peserta membuat direktori pada drive komputer yang tidak tergabung dengan drive sistem terinstal, peserta dapat melakukan manajerial direktori sesuai kebutuhan.

Teknik pengambilan data dari internet meliputi Peserta dapat melakukan proses copy-paste dokumen data text, data gambar dan data video text dari internet, dapat melakukan instalasi aplikasi menggunakan metode copy-paste, aplikasi downloader dan dapat menerapkan aplikasi tersebut download online dan aplikasi downloader. untuk mengambil data video dari internet.

Pengertian surat elektronik (email), membuat Peserta memahami dan mampu membuat alamat eemail mail untuk Pokmas Imanuel.

Peserta dapat mengirim, membaca, membalas dan mendownload isi surat e-mail kepada sesama peserta menggunakan alamat email yang telah dibuat.

Evaluasi Pelatihan Peserta memahami ringkasan materi.

Terdapat 8 bagian materi yang diberikan dalam penerapan TIK di Bijaepunu sebagaimana pada Tabel 1. Dimulai dari konsep TIK, internet dan teknologinya, browser dan pengelolaan driver yang bermanfaat bagi aktifitas pengelolaan ternak sapi di Bijaepunu. Seluruh kegiatan dilakukan secara teori (ceramah) dan praktek dan langsung didampingi. Pendampingan dilakukan pada saat para petani ingin melakukan pendaftaran alamat email, pemasangan modem, instalasi modem dan interkoneksi handphone.

\section{Melakukan evaluasi terhadap pelaksanaan program pengembangan infrastruktur jarinagn dan sumber daya manusia yang telah dilakukan.}

Evaluasi yang diberikan pada program pelatihan ini adalah evaluasi proses, dimana penilaian dilihat dari keikutsertaan peserta dari awal hingga akhir, tingkat keseriusan, kehadiran, respon dalam bentuk pertanyaan, 
kerjasama dengan teman dan kekompakan dalam kerja tim. Evaluasi dilakukan agar peserta lebih serius dalam mengikuti seluruh kegiatan, memiliki semangat untuk terus berusaha menemukan informasi yang berhubungan dengan peternakan dan mau mengembangkan ilmu dalam kelompok atau di masyarakat secara keseluruhan. Dari hasil evaluasi ditentukan 2 orang sebagai peserta dengan nilai paling tinggi dan diberikan reward.

\section{KESIMPULAN}

Pemilihan materi teknologi informasi dan internet untuk kelompok peternak sapi yang memelihara sapi dalam rangka kerjasama NTT-DKI Jakarta adalah cara terbaik untuk meningkatkan SDM peternak terhadap dunia luar yang selama ini belum mereka jangkau. Dengan teknologi internet, para peternak mengetahui tentang apa dan bagaimana kerjasama NTT-DKI Jakarta yang sudah berlangsung dari tahun 2014 tentang ternak sapi dan bagaimana sasaran kerjasama sebenarnya. Dengan internet para peternak mengetahui tentang informasi terkini meliputi harga pasar sapi, strategi pemasaran dan pemeliharaan, pemilihan makanan terbaik, kandang dan informasi lain tentang ternak sapi.

\section{DAFTAR PUSTAKA}

[1] Kompas.com, 2014. Jokowi Teken MOU dengan Pemprov NTT di Peternakan Sapi. http://megapolitan.kompas.com/read/2014/04/29/1306320/Jokowi.Teken.MoU.dengan.Pemprov.NTT. di.Peternakan.Sapi.

[2] Tribunnews.com. 2014. Presiden Jokowi Saksikan Penandatanganan MoU NTT dan DKI. http://www.tribunnews.com/images/editorial/view/1478161/presiden-jokowi-saksikanpenandatanganan-mou-ntt-dan-dki.

[3] Shiizaki, K., Kiryu, R. and Kawabata, K., Fujitsu Limited, 2013. Base transceiver station. U.S. Patent Application 14/087,107

[4] Shiizaki, K., Kiryu, R. and Kawabata, K., Fujitsu Limited, 2013. Base transceiver station. U.S. Patent $8,620,327$.

[5] Sutopo, A.H., 2012. Teknologi informasi dan komunikasi dalam pendidikan. Yogyakarta: Graha Ilmu.

[6] Darmawan, D., 2012. Pendidikan Teknologi Informasi dan Komunikasi. Bandung: PT. Remaja Rosdakarya.

[7] Laumal, F.E., 2015. Pengembangan Sensor Getar Adx1335 sebagai Petunjuk Perawatan Mesin Bubut Horisontal. Prosiding Semnastek.

[8] Laumal, F.E., Suharto, R.S.B. and Peli, Y.S., 2017. MEWUJUDKAN KEMANDIRIAN PEMUDA MELALUI PELATIHAN MULTIMEDIA DAN KOMPUTER AKUNTANSI.

[9] Sofana, I., 2010. Cisco CCNA \& Jaringan Komputer. Informatika. Bandung

[10] Syafrizal, M., 2005. Pengantar jaringan komputer. Penerbit Andi. 